\title{
Current State of Sustainability Reporting: A Case of Public Universities in Western Kenya
}

\author{
Patrick Ojera and Collins O. Odoyo
}

\begin{abstract}
Corporate sustainability reporting, also known as Triple-bottom-line reporting, involves reporting nonfinancial and financial information to a broader set of stakeholders than just shareholders and seek to fortify an organization's ability to manage key risks. The current case is that, the quality, rigor, and utility of sustainability reporting remains contentious with concerns about the suitability of the criteria or standards used to prepare the reports. Despite the rapid increase in the number of companies around the world adopting Global Reporting Initiative standards, little is known about the extent of practice of corporate sustainability reporting in public universities in Kenya. The study selected five universities that had their 2017-18 audited financial reports available online for the readers, which served as the main source of secondary data. The guidelines on corporate sustainability reporting was derived from literature review, which provided key indicators upon which the data from each university was evaluated. It was observed that almost all the institutions recognize the critical role of both internal and external independent audit of financial statements. In conclusion, financial reporting sustainability is guided by strict compliance to the factors of sustainability.
\end{abstract}

Index Terms-Corporate sustainability reporting, Environmental accounting and reporting, Public universities, Sustainability reporting, CSR

\section{INTRODUCTION}

\section{A. Background of the Study}

Corporate Sustainability Reporting (CSR) also known as Triple-bottom-line reporting, involves reporting nonfinancial and financial information to a broader set of stakeholders than just shareholders and seek to fortify an organization's ability to manage key risks [1] [2] [3]. While sustainability reporting is presently voluntary, there is an increasing trend to comply with United Nations sponsored initiatives to implement Sustainable Development Goals (SDGs). According to Vann and White [4] sustainability reporting is a logical extension of corporate financial reporting which is not surprising since accounting, the bedrock of financial reporting, has been billed the language of business, and plays an important role as that language evolves to include information and responsibility beyond the purely financial report [5]. Eccles [6] asserts that stakeholders now demand that accountants must create transparent reports that provide accurate and reliable data, as

Published on April 13, 2020.

Patrick B. Ojera, Masinde Muliro University of Science and

Technology, Kenya.

(e-mail: pbojera@yahoo.com)

Collins Otieno Odoyo, Masinde Muliro University of Science and

Technology, Kenya.

(e-mail: odoyo08@gmail.com) well as a fair picture of overall performance, many companies are now reporting results across the "triple bottom line" of economic, environmental and social performance.

Despite the growing practice of sustainability reporting, universities have not kept pace. Described as generators of knowledge and technology, universities are meant to provide new knowledge, to change paradigms, to aid society in its development and in meeting new challenges [7].

\section{B. The Concept and Practices of Sustainability Reporting}

The concept of sustainability has shaped the development of sustainability reporting. An often used definition of sustainability is the official version of sustainable development anchored in 1987 United Nations World Commission on Environment and Development which states that sustainable development as meeting "the needs of the present without compromising the ability of future generations to meet their own needs" [8], commonly known as the Brundtland Commission Report. It contains within it two key concepts: the concept of 'needs', in particular the essential needs of the world's poor, which demand priority attention; and the notion of limitations imposed by the state of technology and social organization on the environment's ability to meet present and future needs. .

\section{LiterATURE REVIEW}

\section{A. Theoretical Review}

Several theories underpin the concept of sustainability reporting including; Legitimacy theory (LT), Political economy Theory (PET), Public interest theory (PIT), Institutional Legitimacy Theory (ILT), Accountability theory (AT) and stakeholder theory (ST). Gray, Javad, David, Power, and Donald [9] suggest that all the others are variants of Legitimacy theory (LT), termed the 'macrotheory'.... All these have been offered as a theoretical basis for research into social accounting and disclosure [10] [9] and "accepts that society, politics, and economics are inseparable so that issues, such as economic issues, cannot be considered in isolation from social and environmental issues" [10]. Legitimacy theory posits that businesses are bound by the social contract in which the firms agree to perform various socially desired actions in return for approval of its objectives and other rewards, and this ultimately guarantees its continued existence. According to Dowling and Pfeffer [11], Legitimacy theory, at its simplest, argues that organisations can only continue to exist if the society in which they operate perceives that the organisation is operating within the bounds of a value system acceptable to society. Therefore, corporate social disclosure should, 
involve both communication (disclosure) by the organisation as well as addressing norms, values or beliefs of relevant publics or constituents of a society. In this regard, early accounting theory identified the users of accounting information as creditors and shareholders but has expanded over time to include insurers, suppliers, consumer associations, regulators, environmental groups, and the media, among others. Reporting sustainability information plays a central role in fostering corporate accountability and transparency for corporations [12]. .

\section{B. Previous Studies on Sustainability Reporting}

Corporate sustainability reporting (CSR) involves reporting financial and nonfinancial information to key stakeholders on the company's operational, social and environmental activities and its ability to deal with related risks

Radin [13] posits that while there are at least 11 different frameworks, the only one frequently used is the Global Reporting Initiative (GRI) whose Sustainability Reporting Guidelines acknowledge that sustainability is the same as CSR and define a sustainability report as "a report published by a company or organization about the economic, environmental, and social impacts caused by its everyday activities. A sustainability report also presents the organization's values and governance model and demonstrates the link between its strategy and its commitment to a sustainable global economy" ("What Is Sustainability Reporting?" http://bit.ly/1pBsVLq). The GRI's guidelines are the most comprehensive, with 150 different disclosures required for complete conformity. Some companies list all of them and state whether or why any are omitted; others just list those that they are following.

The only country where integrated reporting is mandated is South Africa, [6]. The GRI launched its set of standards in October 2016. These are the first global standards for sustainability reporting and are based on the previous GRI G4 Guidelines, which were phased out on July 1. More recently, Sustainability Accounting Standards Board (SASB) issued its Conceptual Framework in February 2017 and an exposure draft with standards for 79 industries in October 2017; the comment period for the exposure draft ended January 31, 2018. While the GRI focuses on a global audience, SASB focuses on U.S. companies and industries.

Past research has generally found a positive relationship between company size and the voluntary disclosure of sustainability information; the reasons frequently cited include greater exposure to media and higher political visibility [14].

Van Der Ploeg and Vanclay [15] proposed a Sustainability Reporting Assessment Checklist of 10 questions as a functional tool for use by stakeholders to evaluate the content of SRs. For a demonstration of the effectiveness of the checklist, it is applied to a real but anonymous company. The questions cover: accessibility; readability; the use of an established framework (e.g. GRI); incorporation of CSR and sustainability into long-term strategy; consideration of all relevant aspects of operations; use of evidence to support claims; documented stakeholder engagement; supply chain responsibility; documented impacts on all stakeholders (including vulnerable groups and negatively affected groups); and assurance assessment. Sustainability Reporting in Higher Education is limited [7].

\section{Materials AND Methods}

\section{A. Previous Studies on Sustainability Reporting}

This study was a case study of five public universities in the western Kenya. The study focused on these five universities in the western part for easier and effective coordination of data collection process, since and also since their audited financial reports that were instrumental in this study were readily available online. To obtain in depth information, qualitative research approach was applied.

\section{B. Sample Size for the Study}

The sample size for this study was five public universities in the western parts of Kenya. It is important to note that qualitative studies do not focus much on larger sample size, but rather on a number that is able to give saturation on the subject matter being studied.

\section{Sources of Data}

Data was obtained from audited financial reports from the five Kenyan Public Universities in the Western Kenya region. These reports were available online.

\section{Data Collection}

Data collection was based on the "Sustainability Reporting Assessment Checklist" [15] which was applied on five the universities, to evaluate the creditability of the annual and sustainability-related reports. Van Der Ploeg and Vanclay [15] developed a checklist to evaluate the credibility of sustainability-related reports.

\section{FINDINGS AND Discussions}

This part of the paper outlines the findings of the study. The research findings obtained using the administered questionnaire established that the institutions under study had their reports publicly available in the appropriate languages, written in a clear and concise way, readable by the relevant stakeholders.

Respondents were also asked as to whether their company used an established reporting framework such as the GRI. The results were obtained as in the table below.

TABLE I: USE OF ESTABLISHED REPORTING FRAMEWORK

\begin{tabular}{lr}
\hline \hline Institutions & Responses \\
\hline MMUST & $\mathrm{NO}$ \\
Masen University & $\mathrm{NO}$ \\
Egerton University & $\mathrm{NO}$ \\
Moi University & $\mathrm{NO}$ \\
Kibabii University & YES \\
\hline \hline
\end{tabular}

From the table, majority (4 of 5) of the institutions in the region under study indicated that they do not use an established reporting framework such as the GRI. This 
indicated that most universities in the area of this study were still far from incorporating established framework in their reporting.

The respondents were also asked as to whether there was an adequate description of how the company incorporates CSR and sustainable development in to the formulation of its long term organization strategy. The analysis was obtained as tabulated below.

TABLE II: DESCRIPTION ON INCORPORATING CSR

\begin{tabular}{lr}
\hline \hline Institutions & Response \\
\hline MMUST & NO \\
Masen University & NO \\
Egerton University & YES \\
Moi University & NO \\
Kibabii University & YES \\
\hline \hline
\end{tabular}

The analysis shows that majority (3 of 5) of the institutions in the region do not have adequate description of how they incorporated CSR and sustainable development into their formulation of long term organization strategy. It was clear from the findings that, these organization are keen on their other core mandates at the expense of the environment around them. There were no clear indication on how the also contribute to making the environment better other than the two universities.

Another issue captured by the questionnaire was whether the institution discusses sustainable issues of all relevant aspects of their operations. The analysis is tabulated below.

TABLE III: DISCUSSES SUSTAINABLE ISSUES OF OPERATIONS

\begin{tabular}{lr}
\hline \hline Institutions & Response \\
\hline MMUST & YES \\
Masen University & NO \\
Egerton University & YES \\
Moi University & YES \\
Kibabii University & YES \\
\hline \hline
\end{tabular}

Majority of the responses indicated that their institution discusses sustainable issues of all relevant aspects of its operations. Only one institution (Maseno University) did not observe the said variable. This was so encouraging, to see that the institutions minded the sustainability of the activities that were at the time being carried out. They were focused more on the continuity of their institutions over relatively longer periods.

The other issue of financial reporting sustainability captured by the questionnaire was whether the company provided adequate evidence (e.g. data) to support the claims they made in relation to all indicators and/or topics being discussed. The analysis is given below.

TABLE IV: PROVISION OF ADEQUATE EVIDENCE

\begin{tabular}{lr}
\hline \hline Institutions & Response \\
\hline MMUST & NO
\end{tabular}

Masen University

YES

Egerton University

NO

Moi University

NO

Kibabii University

YES

Many institutions did not observe this variable of financial reporting sustainability. They never reported on all the indicators that constituted the operation that were taking places in such institutions. This exposed to some extent inadequate accountability by the management of such institutions. It was therefore necessary that such institutions find a way of reporting on all the indicators and aspects of their operations.

Another question addressed by the questionnaire was whether the institutions identified all their stakeholders, explained how they were identified, outlined the expectations and interests of their stakeholders. The analysis was tabulated as shown below.

TABLE V: STAKEHOLDERS IDENTIFICATION

\begin{tabular}{lr}
\hline \hline Institutions & Response \\
\hline MMUST & $\mathrm{NO}$ \\
Masen University & $\mathrm{NO}$ \\
Egerton University & $\mathrm{NO}$ \\
Moi University & $\mathrm{NO}$ \\
Kibabii University & YES \\
\hline \hline
\end{tabular}

Almost all institutions studied (4 of 5) did not identify all its stakeholders, neither did they explain how they identify them. They also failed to outline the expectations and interests of their stakeholders. Only Kibabii University observed this variable of financial reporting sustainability.

As to whether the institutions in the region under study assessed the sustainability issues associated with all upstream and downstream entities in the supply chain, the tabulated analysis was obtained.

TABLE V: ASSESSMENT OF SUSTAINABILITY ISSUES

\begin{tabular}{lr}
\hline \hline Institutions & Response \\
\hline MMUST & NO \\
Masen University & NO \\
Egerton University & NO \\
Moi University & NO \\
Kibabii University & YES \\
\hline \hline
\end{tabular}

Almost all (4 of 5) the institutions under study did not comply with this variable of financial reporting sustainability. Only Kibabii University assessed the sustainability issues associated with all upstream and downstream entities in the supply chain.

The question as to whether the institution adequately discussed the impacts of its activities (both positive and negative) on all its stakeholders, including vulnerable groups and negatively affected groups.

The open ended question as to whether the company established the credibility of its sustainability report, for example is there an independent assurance report?, resulted in varied response that included:

1) There is presence of internal audit department 
with the responsibility of ensuring compliance to regulatory frameworks.

2) The university being reluctant on this variable of financial reporting sustainability.

3) Presence of reports on financial statements from the National Audit Office- office of the Auditor General.

\section{CONCLUSION}

In conclusion, financial reporting sustainability is, however, guided by compliance and continues observation to these dimensions of the study. The institutions under study rarely observed the variables which included; whether the institutions used an established reporting framework such as the GRI, whether they assessed the sustainability issues associated with all upstream and downstream entities in the supply chain and also whether they provided adequate evidence (e.g. data) to support the claims it makes in relation to all indicators and/or topics being discussed.

The study indicates that Kibabii University is complies with all the financial reporting sustainability variables of the study. It is also observed that almost all the institutions recognize the critical role of both internal and external independent audit of financial statements.

\section{RECOMMENDATIONS}

Sustainability is not a new concept in financial reporting. Its overall purpose is to disclose how the institutions create value. Institutions of higher learning are not left out of adherence to financial reporting sustainability. From the findings of the study it is recommended that the institutions studied ought to improve their reporting specifically, in regard to provision of adequate evidence, identification of stakeholders and outlining their expectations, assessment of sustainability issues associated with all upstream and downstream entities in the supply chain, including use of established reporting framework such as the GRI.

It is necessary that institutions find ways of reporting on all the indicators and aspects of their operations.

Finally, it is recommended that the institutions ought to consider mechanisms that boost control on compliance and risk assessment like establishment of independent audit functions.

\section{LIST OF ABBREVIATIONS}

$\begin{array}{ll}\text { AT } & \text { Accountability Theory } \\ \text { CSR } & \text { Corporate Sustainability Reporting } \\ \text { GRI } & \text { Global Reporting Initiatives } \\ \text { ILT } & \text { Institutional Legitimacy Theory } \\ \text { LT } & \text { Legitimacy Theory } \\ \text { PET } & \text { Political Economic Theory } \\ \text { PIT } & \text { Public Interest Theory } \\ \text { SDG } & \text { Sustainable Development Goals } \\ \text { ST } & \text { Stakeholders Theory. }\end{array}$

\section{ACKNOWLEDGMENT}

We would like to take this opportunity to acknowledge all the lead respondents from all the five universities that took part in this study. They all made this study successful by offering themselves to reach out to their colleagues with an online questionnaire that was developed. Special thanks also goes to individual respondents about ten from each university for taking their time to respond to the questions on the questionnaires.

\section{REFERENCES}

[1] Durden, C., (2008), "Towards a socially responsible management control system", Accounting, Auditing \& Accountability Journal, Vol. 21 Iss 5 pp. 671 - 694. Accessed on 11th July, 209 from: https://www.researchgate.net/publication/227428871_Towards_a_Soc ially Responsible Management Control System

[2] Global Reporting Initiative, (2013), 2013 Global Conference on Sustainability and Reporting. Accessed on 11july, 2019 from: https://www.globalreporting.org/resourcelibrary/2013-GRI-GlobalConference-in-Review.pdf

[3] KPMG, (2002), KPMG International Survey of Corporate Sustainability Reporting 2002. Accessed on 11th July, 2019 from: https://www.researchgate.net/publication/254746739_KPMG_Interna tional Survey of Corporate Sustainability Reporting 2002

[4] Vann, J. W., \& White, G. B., (2014), journal of Business \& Economics Research - December 2004 Volume 2, Number 12, 17-30

[5] Tilt, C. A., (2009) Corporate Responsibility, Accounting and Accountants Chapter Corporate Responsibility, Accounting and Accountants Carol A. Tilt, S.O. Idowu, W.L. Filho (eds.), Professionals' Perspectives of Corporate Social 11 Responsibility, Springer-Verlag Berlin Heidelberg 2009. DOI 10.1007/978-3-64202630-0 2, C

[6] Eccles, R. G., Herz, R. H., Keegan, E. M., and David M.H. Phillips, D. M. H., (2001). The Value Reporting Revolution: Moving Beyond the Earnings Game:, Wiley, New York, 2001, xvii +349 pp., February 2002, The International Journal of Accounting 37(1):145-148. DOI: 10.1016/S0020-7063(02)00130-9

[7] Satinder Singh and Ashwarya Sharma (2015) "Corporate Social Responsibility practices in India: Analysis of public companies" International journal of business quantitative economics and applied management research, Volume 1, issue 11, April 2015 Pg.no 33-44.

[8] United Nations World Commission on Environment and Development, (2000), Our Common Future: Report of the World Commission on Environment and Development, http://bit.ly/2JJbvuN

[9] Gray, R., Javad, David, M., Power, M., and Donald, C., (1996). Sinclair Social and Environmental Disclosure and Corporate Characteristics: A Research Note and Extension.

[10] Deegan, C., 2000, Financial Accounting Theory, McGraw Hill Book Company, Sydney.

[11] Dowling, J. and Pfeffer, J. (1975) Organizational Legitimacy: Social Values and Organizational Behavior. Pacific Sociological Review, 18, 122-136. https://doi.org/10.2307/1388226

[12] Adams, CA \& Whelan, G 2009, 'Conceptualising future change in corporate sustainability reporting', Accounting, Auditing and Accountability Journal, vol. 22, no. 1, pp. $118-143$.

[13] Radin, A. J., (2016)., "What Is Sustainability Reporting?" http://bit.ly/1pBsVLq

[14] Pandit, G. M., (2016), The Current State of Sustainability Reporting by Smaller S\&P 500 Companies What Do Businesses Choose to Disclose? CMA June 2016 Issue.

[15] Van Der Ploeg, L., \& Vanclay, F. (2013). Credible Claim or Corporate Spin? A Checklist to Evaluate Corporate Sustainability Reports. Journal of Environmental Assessment Policy and Management, 15(3), 1-21. https://doi.org/10.1142/S1464333213500129 